\title{
MODEL KETERKAITAN NILAI PERUSAHAAN DAN RETURN SAHAM BERBASIS RASIO KEUANGAN PADA INDUSTRI PULP DAN KERTAS
}

\author{
THE MODEL OF CORRELATION BETWEEN FIRM VALUE AND STOCK \\ RETURN BASEDFINANCIAL RATIOS IN THE PULP AND PAPER INDUSTRY
}

\author{
Okalesa $^{1}$, Onny Setyawan ${ }^{2}$, Mimelientesa $\operatorname{Irman}^{3}$ \\ Institut Bisnis dan Teknologi Pelita Indonesia ${ }^{1,2,3}$ \\ okalesa@gmail.com
}

\begin{abstract}
An investor that want to do the investment on the capital market will expecting the high return with low risk. Before do the investment, an investor will observing how the company value was going in the market. Other than stock price, the company value nor stock return could be affected by some factors one or the other is the company financial performance. This research aims to examine the effect of Current Ratio, Debt to Equity Ratio and Return On Asset toward Company Value (Tobin's Q) and Stock Return. The used sample was pulp and paper sub sector of manufacturing company periods 20122017 that listed in Indonesia Stock Exchange using purposive sampling of the sampling technique. The data analysis technique used is path analysis by WarpPLS 4.0. The results of hypothesis showed Current Ratio has significant negative effect on Company Value and non-significant positive effect on Stock Return. Debt to Equity Ratio has significant negative effect on Company Value and non-significant negative effect on Stock Return. Return On Asset has significant positive effect on Company Value and Stock Return. Whereas Company Value has significant negative effect on Stock Return.
\end{abstract}

Keywords : Current Ratio, Debt to Equity Ratio, Return On Asset, Company Value, Tobin's Q, Stock Return, WarpPLS

\begin{abstract}
ABSTRAK
Seorang investor yang ingin melakukan investasi di pasar modal, tentunya mengharapkan return yang tinggi dengan risiko yang kecil. Sebelum melakukan investasi, investor akan memperhatikan bagaimana nilai suatu perusahaan di mata pasar. Namun, selain harga saham, nilai perusahaan maupun return saham dapat dipengaruhi oleh beberapa faktor yang salah satu diantaranya adalah kinerja keuangan perusahaan. Penelitian ini bertujuan untuk menguji pengaruh Current Ratio, Debt To Equity Ratio dan Return on Asset terhadap Nilai Perusahaan (Tobin's Q) dan Return Saham. Sampel yang digunakan adalah perusahaan manufaktur sub sektor pulp dan kertas periode 20122017 yang terdaftar di Bursa Efek Indonesia dengan menggunakan teknik sampling purposive sampling. Teknik analisis data yang digunakan adalah analisis jalur menggunakan WarpPLS 4.0. Hasil pengujian hipotesis menunjukkan bahwa Current Ratio berpengaruh negatif signifikan terhadap Nilai Perusahaan dan berpengaruh positif tidak signifikan terhadap Return Saham. Debt to Equity Ratio berpengaruh negatif signifikan terhadap Nilai Perusahaan dan berpengaruh negatif tidak signifikan terhadap Return Saham. Return on Asset berpengaruh positif signifikan terhadap Nilai
\end{abstract}


Perusahaan dan Return Saham. Sedangkan Nilai Perusahaan berpengaruh negatif signifikan terhadap Return Saham.

Kata Kunci : Current Ratio, Debt to Equity Ratio, Return On Asset, Nilai Perusahaan, Tobin's Q, Return Saham, WarpPLS

\section{PENDAHULUAN}

Setiap perusahaan memiliki tujuan sederhana yang sama, yaitu bagaimana agar perusahaan yang didirikan memiliki nilai yang baik di mata pasar dan mampu mengelola keuangannya untuk memperoleh keuntungan/laba. Namun, saat ini semakin banyak terlahir perusahaanperusahaan yang berkualitas dan menambah daya saing pada dunia perdagangan terutama pasar modal. Pasar modal adalah pasar untuk berbagai instrument jangka panjang yang bisa diperjual-belikan, baik dalam bentuk hutang maupun modal sendiri, baik yang diterbitkan oleh pemerintah, public authorities, maupun perusahaan swasta (Husnan, 2009).

Berbagai emiten terlibat dalam pasar modal yang terbagi dalam beberapa sektor dan salah satunya adalah sektor manufaktur. Sektor manufaktur Indonesia merupakan nomor 4 tertinggi di dunia berdasarkan laporan United Nations Industrial Development Organization (UNIDO) yang mengukur sektor manufaktur negara-negara di dunia. Hal tersebut mencerminkan bahwa sektor manufaktur berperan besar dalam perekonomian Indonesia. Salah satu sub sektor dari sektor manufaktur adalah pulp dan kertas, dimana sub sektor pulp dan kertas merupakan salah satu industri yang memiliki kedudukan yang tinggi di mata dunia, yaitu peringkat ke9 untuk produsen pulp dan peringkat ke6 untuk produsen kertas berdasarkan data dari Asosiasi Pulp dan Kertas Indonesia (APKI).
Menyadari pentingnya keberadaan sektor manufaktur bagi perdagangan dan perekonomian Indonesia, maka dari itu dapat dilihat nilai ekspor tersebut selama 3 periode, sebagai berikut :

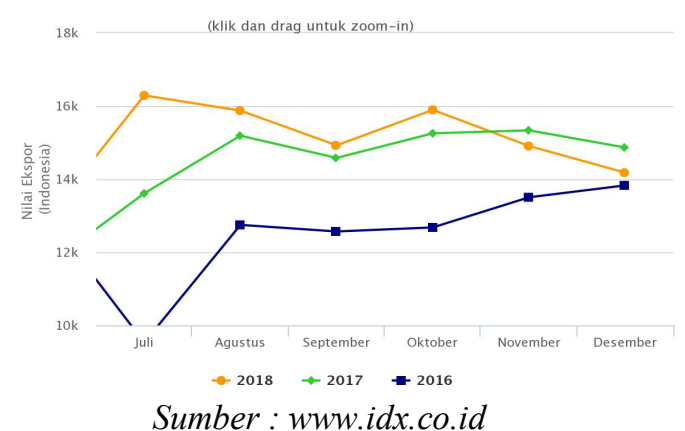

Gambar 1. Nilai Ekspor Sektor Manufaktur Periode 2016-2018

Berdasarkan grafik diatas, dapat dilihat bahwa pada setiap tahun memiliki pergerakannya masing-masing, seperti pada tahun 2016 dan 2017 yang cenderung naik dan sedangkan pada tahun 2018 yang cenderung turun. Dengan nilai ekspor tertinggi melebihi 16.000 yang dicapai pada tahun 2018 dan nilai ekspor terendah lebih rendah dari 10.000 yang dicapai pada tahun 2016. Ketidakstabilan tersebut dapat dipengaruhi oleh beberapa hal seperti faktor-faktor internal maupun eksternal lainnya. Namun, ketidakstabilan nilai ekspor tersebut akan berpengaruh pada beberapa hal terutama harga saham, dimana nilai ekspor menggambarkan kemampuan dalam menghasilkan daya jual kepada Negara lain, sehingga nilai ekspor yang rendah akan tercermin pada harga saham yang mencerminkan bahwa terdapatnya faktor yang memicu harga saham tersebut rendah dan salah 
satu faktor tersebut adalah dari nilai ekspor itu sendiri.

Dalam dunia pasar modal, tidak terlepas dari kemampuan perusahaan dalam menarik investor untuk berinvestasi. Beberapa hal akan menjadi pertimbangan investor sebelum berinvestasi, seperti nilai ekspor, nilai perusahaan, kinerja perusahaam, dan beberapa faktor lainnya, tetapi salah satunya adalah harga saham. Harga saham adalah harga yang ditentukan secara lelang kontinu (Susanto, 2002). Harga saham mencerminkan nilai perusahaan. Salah satu harga saham yang dapat mencerminkan indeks atas seluruh harga saham yang tercatat di Bursa Efek Indonesia adalah Indeks Harga Saham Gabungan (IHSG) yang menggambarkan pergerakan harga saham. Berikut grafik IHSG Periode 2012-2017, antara lain :

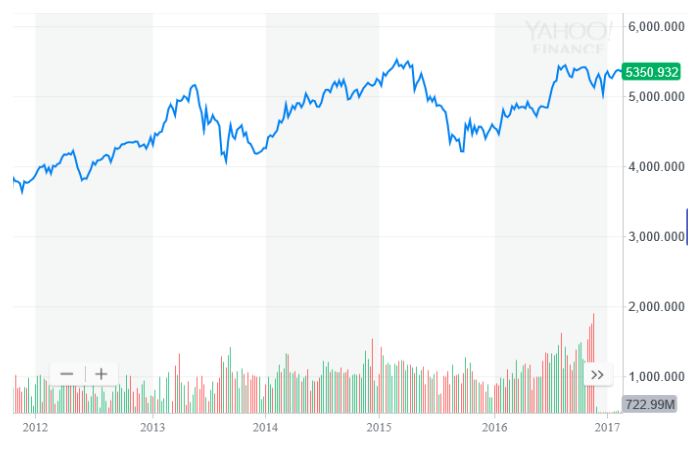

Sumber: $\underline{w w w . f i n a n c e . y a h o o . c o m}$

Gambar 2. Indeks Harga Saham (IHSG) Periode 2012-2017

Berdasarkan grafik diatas, dapat dilihat bahwa pergerakan harga saham periode 2012-2017 relatif naik turun atau tidak stabil, tetapi dapat dikatakan bahwa harga saham tersebut cenderung naik. Hal tersebut dapat mencerminkan bahwa secara keseluruhan harga saham pada perusahaan-perusahaan yang tercatat di Bursa Efek Indonesia (BEI) dalam kondisi tidak stabil dari tahun ke tahun dimana hal tersebut dapat dipengaruhi oleh beberapa faktor eksternal seperti suku bunga, nilai kurs, tingkat inflasi, maupun faktor-faktor lainnya.

Ketidakstabilan harga saham dapat berpengaruh terhadap nilai perusahaan dimana harga saham menggambarkan nilai pasar suatu perusahaan dan terhadap return saham dimana semakin tinggi harga saham maka semakin tinggi return yang diperoleh. Nilai perusahaan merupakan gambaran seberapa besar nilai pada suatu perusahaan di mata pasar, atau bisa juga disebut dengan nilai pasar perusahaan. Enterprise value (EV) atau firm value (nilai perusahaan) merupakan konsep penting bagi investor, karena merupakan indikator bagi pasar menilai perusahaan secara keseluruhan.

Salah satu parameter dalam mengukur nilai perusahaan adalah menggunakan Tobin's Q. Tobin's Q tidak hanya membandingkan harga saham dengan pendapatan ataupun nilai buku, tetapi melibatkan seluruh aset perusahaan sehingga Tobin's Q menjadi salah satu alat pengukuran paling akurat dalam mengukur nilai perusahaan. Semakin tinggi nilai Tobin's Q akan semakin baik karena hal itu memperlihatkan bahwa perusahaan memiliki kemungkinan pertumbuhan yang baik di masa yang akan datang (Putri, et.al, 2016).

Setiap investor memiliki tujuan yang sama dalam berinvestasi, yaitu mendapatkan return yang tinggi. Kemakmuran seorang investor merupakan salah satu aspek penting yang harus dijaga dan diperhatikan oleh suatu perusahaan. Untuk mengetahui perusahaan yang layak ditanamkan saham, banyak faktor yang dapat dijadikan pertimbangan keputusan investasi dan salah satunya adalah return saham. Return saham yang dihasilkan dapat berupa keuntungan maupun kerugian. Semakin tinggi harga 
saham maka semakin tinggi return saham.

Selain harga saham, kinerja keuangan perusahaan juga menjadi faktor pengambilan keputusan dalam melakukan investasi. Harga saham juga merupakan cerminan baik tidaknya kinerja keuangan suatu perusahaan. Setiap perusahaan yang listing di pasar modal memiliki laporan keuangan yang bersifat transparan yang dapat diakses dengan mudah di Bursa Efek Indonesia (BEI), dimana laporan tersebut menjadi informasi sebagai indikator dalam pengukuran kinerja keuangan. Kinerja keuangan perusahaan dapat diukur dengan menggunakan rasio keuangan. Rasio keuangan tersebut akan menjadi kunci dalam pengambilan keputusan bagi calon investor.

Bagi investor, perlu diketahui bagaimana suatu perusahaan mengelola keuangan perusahaannya, yaitu untuk mengetahui apakah perusahaan tersebut likuid. Likuid tidaknya suatu perusahaan dapat diukur dengan menggunakan rasio likuiditas dan salah satu rasio tersebut adalah Current Ratio, yaitu untuk mengetahui bagaimana kemampuan perusahaan dalam memenuhi kewajiban lancar dengan aktiva lancar. Selain itu, perlu juga diketahui bagaimana kemampuan perusahaan melunasi seluruh kewajiban dengan seluruh ekuitas yang dimiliki yang dapat diukur dengan rasio Debt to Equity Ratio. Dalam berinvestasi, investor mengutamakan perusahaan yang mampu menghasilkan laba yang tinggi sehingga dapat memberikan kemakmuran bagi investor, maka dari itu rasio Return On Asset perlu dipertimbangkan dan dianalisa. Jadi, sebelum berinvestasi seorang investor akan menganalisa kinerja keuangan perusahaan yang di pasar modal dengan melihat perusahaan mana yang likuid dengan tidak memiliki hutang yang tinggi dan mampu menghasilkan laba yang tinggi sehingga akan memiliki nilai perusahaan yang baik di pasar dimana tingginya nilai perusahaan akan memberikan return yang tinggi juga.

Berdasarkan penelitianpenelitian sebelumnya, dapat dilihat bagaimana pengaruh rasio-rasio keuangan terhadap nilai perusahaan dan return saham. Pernyataan bahwa Current Ratio (CR) berpengaruh negatif signifikan terhadap nilai perusahaan didukung oleh penelitian Jacob \& Taslim (2017), namun bertentangan dengan penelitian Putri, et.al, (2016); Adelina, et.al, (2014); Chotimah \& Amanah (2013) yang menyatakan bahwa Current Ratio (CR) tidak berpengaruh signifikan terhadap nilai perusahaan. Sedangkan, Current Ratio (CR) berpengaruh positif signifikan terhadap return saham didukung oleh penelitian Dewi (2016), namun hasil dari penelitian Erari (2014), Febrioni (2016); Chotimah \& Amanah (2013) bertolak belakang dengan penelitian Dewi (2016) yang menyatakan bahwa Current Ratio (CR) tidak berpengaruh signifikan terhadap return saham.

Bukan hanya hutang lancar, total hutang juga merupakan aspek penting dalam mengukur kinerja keuangan perusahaan. Debt to Equtiy Ratio menggambarkan sampai sejauhmana modal pemilik dapat menutupi utangutang kepada pihak luar (Harahap, 2008). Rasio ini untuk melihat apakah suatu perusahaan mampu melunasi seluruh kewajiban yang dimiliki dengan menggunakan ekuitas yang ada. Rasio ini juga memberikan petunjuk umum tentang kelayakan dan risiko keuangan perusahaan (Kasmir, 2015).

Berdasarkan hasil penelitian dari para peneliti terdahulu, dapat diketahui bahwa menurut Chotimah \& Amanah (2013) bahwa Debt to Equity Ratio (DER) berpengaruh positif 
signifikan terhadap nilai perusahaan, tetapi pernyataan tersebut bertolak belakang dengan hasil penelitian Mahendra, et.al, (2012); Sianturi (2015) yang menyatakan bahwa Debt to Equity Ratio (DER) berpengaruh negatif tidak signifikan terhadap nilai perusahaan. Kedua pernyataan tersebut tidak didukung oleh penelitian Adelina, et.al, (2014) yang menyatakan bahwa Debt to Equity Ratio (DER) tidak berpengaruh signifikan terhadap nilai perusahaan. Menurut penelitian Siburian \& Daulay (2013); Susilowati \& Turyanto (2011), Dewi (2016); Chotimah \& Amanah (2013) menunjukkan bahwa Debt to Equity Ratio (DER) berpengaruh positif signifikan terhadap return saham. Tetapi, pernyataan tersebut ditentang oleh hasil penelitian Gunadi \& Kesuma (2015) yang menyatakan bahwa Debt to Equity Ratio (DER) berpengaruh negatif signifikan terhadap return saham. Namun, berbeda dengan hasil penelitian Erari (2014) yang menyatakan bahwa Debt to Equity Ratio (DER) tidak berpengaruh terhadap return saham.

Pernyataan bahwa Return On Assets (ROA) berpengaruh positif signifikan terhadap nilai perusahaan didukung oleh Putri, et.al (2016). Pernyataan tersebut berbeda dengan hasil penelitian Chotimah \& Amanah (2013) yang menyatakan bahwa Return On Asset (ROA) berpengaruh negatif signifikan terhadap nilai perusahaan. Namun, bertentangan dengan penelitian Tjandrakirana \& Monika (2014) yang menyatakan bahwa Return On Assets (ROA) tidak berpengaruh signifikan terhadap nilai perusahaan. Sedangkan, hasil penelitian yang menyatakan bahwa Return On Asset (ROA) berpengaruh positif signifikan terhadap return saham didukung oleh Gunadi \& Kesuma (2014), Dewi (2016), Erari (2014), serta Chotimah \& Amanah (2013). Bertentangan dengan penelitian sebelumnya, hasil penelitian Siburian \& Daulay (2013), Syahputri \& Herlambang (2015) yang menyatakan bahwa Return On Asset (ROA) berpengaruh positif tidak signifikan terhadap return saham. Tetapi, hasil penelitian Mahmudah \& Suwitho (2016) menyatakan bahwa Return On Assets (ROA) berpengaruh negatif tidak signifikan terhadap return saham. Ketiga hasil penelitian tersebut tidak didukung oleh penelitian Susilowati \&Turyanto (2011); Febrioni (2016); Oktyawati \& Agustia (2014) yang menyatakan bahwa Return On Assets (ROA) tidak berpengaruh signifikan terhadap return saham.

Berhubungan dengan pengaruh nilai perusahaan terhadap return saham, menurut penelitian Rahman \& Khairunnisa (2016); Kurniadi, et.al, (2013), nilai perusahaan berpengaruh positif signifikan terhadap return saham. Tetapi, perlu diteliti kembali untuk mengetahui kemungkinan nilai perusahaan tidak berpengaruh terhadap return saham. Berdasarkan research gap yang telah dipaparkan diatas, maka hal tersebut memperkuat alasan perlu dilakukan penelitian atas pengaruh Current Ratio, Debt to Equity Ratio, dan Return On Asset terhadap Nilai Perusahaan dan Return Saham.

Dalam penelitian ini, yang menjadi tujuan dari penelitian yang dilakukan adalah sebagai berikut : (1) Menganalisis dan mengetahui pengaruh Current Ratio (CR) terhadap Nilai Perusahaan pada Perusahaan Manufaktur Sub Sektor Pulp dan Kertas Yang Terdaftar di Bursa Efek Indonesia Periode 2012-2017. (2) Menganalisis dan mengetahui pengaruh Debt to Equity Ratio (DER) terhadap Nilai Perusahaan pada Perusahaan Manufaktur Sub Sektor Pulp dan Kertas Yang Terdaftar di Bursa Efek Indonesia Periode 2012-2017. (3) Menganalisis 
dan mengetahui pengaruh Return on Asset (ROA) terhadap Nilai Perusahaan pada Perusahaan Manufaktur Sub Sektor Pulp dan Kertas Yang Terdaftar di Bursa Efek Indonesia Periode 20122017. (4) Menganalisis dan mengetahui pengaruh Current Ratio (CR) terhadap Return Saham pada Perusahaan Manufaktur Sub Sektor Pulp dan Kertas Yang Terdaftar di Bursa Efek Indonesia Periode 2012-2017. (5) Menganalisis dan mengetahui pengaruh Debt to Equity Ratio (DER) terhadap Return Saham pada Perusahaan Manufaktur Sub Sektor Pulp dan Kertas Yang Terdaftar di Bursa Efek Indonesia Periode 2012-2017. (6) Menganalisis dan mengetahui pengaruh Return on Asset (ROA) terhadap Return Saham pada Perusahaan Manufaktur Sub Sektor Pulp dan Kertas Yang Terdaftar di Bursa Efek Indonesia Periode 20122017. (7) Menganalisis dan mengetahui pengaruh Nilai Perusahaan terhadap Return Saham pada Perusahaan Manufaktur Sub Sektor Pulp dan Kertas Yang Terdaftar di Bursa Efek Indonesia Periode 2012-2017.

Dalam penelitian ini tentunya memiliki manfaat bagi beberapa pihak, antara lain sebagai berikut : (1) Bagi Investor, dengan adanya penelitian ini diharapkan investor dapat mengetahui bagaimana keadaan dan posisi keuangan suatu perusahaan sehingga hal tersebut dapat menjadi dasar pertimbangan untuk keputusan investasi agar mencapai hasil investasi yang diinginkan. (2) Bagi Perusahaan, dengan adanya penelitian ini diharapkan dapat membantu dalam meningkatkan nilai perusahaan serta meningkatkan kepuasan investor sehingga dapat menjadi evaluasi agar memiliki kinerja keuangan yang lebih baik. (3) Bagi Akademis, diharapkan dengan adanya penelitian ini dapat membantu para akademis selanjutnya sebagai referensi dalam melaksanakan penelitian dan memperkuat hasil penelitian ini maupun peneliti terdahulu.

Current Ratio mengukur kemampuan perusahaan dalam melunasi hutang/kewajiban jangka pendek menggunakan aset/aktiva lancar. CR yang tinggi menandakan perusahaan memiliki kredibilitas yang tinggi dan dapat dinyatakan perusahaan likuid dimana hal tersebut akan tercermin di pasar yang mempengaruhi nilai perusahaan sehingga semakin tinggi CR maka semakin tinggi nilai perusahaan. Pengaruh Current Ratio terhadap nilai perusahaan telah dibuktikan dari hasil penelitian yang dilakukan oleh Jacob \& Taslim (2017).

Debt to Equity Ratio mengukur kemampuan perusahaan dalam melunasi hutang/kewajiban dengan ekuitas. DER yang tinggi akan menunjukkan bahwa perusahaan kurang mampu memenuhi kewajiban yang dimiliki sehingga akan mempengaruhi nilai perusahaan di mata pasar yang dinilai kurang baik. Pengaruh Debt to Equity Ratio terhadap Nilai Perusahaan telah dibuktikan dari hasil hasil penelitian yang dilakukan oleh Mahendra, et.al, (2012), Sianturi (2015), Chotimah, et.al (2013).

Return On Asset mengukur seberapa besar laba yang diperoleh dengan total aset. Perusahaan yang mampu menginvestasikan total aset agar memperoleh laba akan memiliki ROA yang tinggi sehingga akan mempengaruhi nilai perusahaan di mata pasar karena pasar tertarik akan perusahaan yang mampu menghasilkan return yang tinggi. Pengaruh Return On Asset terhadap Nilai Perusahaan telah dibuktikan dari hasil penelitian yang dilakukan oleh Putri, et.al (2016); Chotimah, et.al (2013).

Current Ratio yang tinggi mencerminkan kinerja keuangan yang baik sehingga dapat mempengaruhi 
peningkatan pada harga saham dimana meningkatnya harga saham akan meningkatkan return saham. Pengaruh Current Ratio terhadap Return Saham telah dibuktikan dari hasil penelitian yang dilakukan oleh Dewi (2016).

Debt to Equiy Ratio yang tinggi mencerminkan perusahaan memiliki hutang yang tinggi dimana hal tersebut akan menyebabkan penilaian yang kurang baik dimata pasar yang akan berdampak pada mempengaruhi penurunan return saham. Pengaruh Debt to Equity Ratio terhadap Return Saham telah dibuktikan dari hasil penelitian yang dilakukan oleh Gunadi \& Kesuma (2015); Siburian \& Daulay (2013); Susilowati \& Turyanto (2011); Dewi (2016); Chotimah, et.al (2013).

Return On Asset yang tinggi mencerminkan perusahaan mampu memperoleh laba yang tinggi atas investasi aset yang dilakukan. Hal tersebut akan memberikan pandangan positif terhadap investor dan pasar bahwa perusahaan mampu menghasilkan laba yang tinggi sehingga mempengaruhi return saham yang akan diperoleh investor dimana semakin tinggi ROA maka semakin tinggi return saham. Pengaruh Return On Asset (ROA) terhadap Return Saham telah dibuktikan dari hasil penelitian yang dilakukan oleh Gunadi \& Kesuma (2014); Dewi (2016); Erari (2014); Chotimah, et.al, (2013).

Nilai Perusahaan yang tinggi menggambarkan bahwa nilai suatu perusahaan di pasar dalam kategori baik dimana penilaian tersebut dipengaruhi oleh kinerja keuangan perusahaan. Nilai perusahaan tercermin dari harga saham sehingga apabila nilai perusahaan meningkat maka akan mempengaruhi return saham yang turut meningkat. Pengaruh Nilai Perusahaan terhadap Return Saham telah dibuktikan dari hasil penelitian yang dilakukan oleh
Rahman \& Khairunnisa (2016); Kurniadi, et.al, (2013).

\section{METODE PENELITIAN Populasi}

Populasi adalah keseluruhan jumlah yang terdiri atas obyek atau subyek yang mempunyai karakteristik dan kualitas tertentu yang diterapkan oleh peneliti untuk diteliti dan kemudian ditarik kesimpulannya (Sujarweni, 2017). Populasi yang akan digunakan pada penelitian ini adalah seluruh perusahaan manufaktur sektor pulp dan kertas yang terdaftar di Bursa Efek Indonesia (BEI) periode 20122017 yang diperoleh dari www.idx.co.id, yaitu berjumlah 9 perusahaan.

\section{Sampel}

Sampel adalah bagian dari sejumlah karakteristik yang dimiliki oleh populasi yang digunakan untuk penelitian (Sujarweni, 2017). Dalam pengambilan sampel untuk penelitian ini, teknik sampling yang digunakan adalah purposive sampling dimana setelah sampling dilakukan maka jumlah sampel yang memenuhi kriteria adalah 8 perusahaan. Kriteria sampel yang digunakan dalam penelitian ini antara lain : (1) Perusahaan yang merupakan perusahaan manufaktur sub sektor Pulp dan Kertas yang terdaftar di Bursa Efek Indonesia (BEI). (2) Perusahaan-perusahaan go public sub sektor Pulp dan Kertas yang listing setelah tahun 2012.

\section{Definisi Operasional Variabel}

Dalam penelitian ini digunakan 2 jenis variabel, yaitu variabel laten eksogen $(\mathrm{X})$ dan variabel laten endogen (Y). 


\section{Variabel Laten Endogen (Y)}

Variabel laten endogen merupakan tipe variabel yang dipengaruhi oleh variabel lain baik secara langsung (direct) maupun tidak langsung (indirect) dan disimbolkan dengan $\eta$ (dibaca ETA) (Ghozali \& Latan, 2014). Variabel laten endogen yang digunakan dalam penelitian ini adalah Nilai Perusahaan dan Return Saham.

Menurut Husnan (2009), nilai perusahaan adalah nilai yang dibutuhkan investor untuk mengambil keputusan investasi yang tercermin dari harga pasar perusahaan. Tobin's Q ratio dipopulerkan oleh James Tobin yang menyatakan bahwa nilai pasar perusahaan mempunyai nilai yang sebanding dengan nilai total aset. Nilai Tobin's $\mathrm{Q}>1$ mengartikan bahwa perusahaan overvalued, sedangkan Tobin's $\mathrm{Q}<1$ mengartikan bahwa perusahaan unvervalued. Perhitungan Nilai Perusahaan menggunakan Tobin's $\mathrm{Q}$ dapat menggunakan rumus sebagai berikut :

\section{Total Market Value of Firm Total Asset Value of Firm}

Dimana:

Total Market Value of Firm = Shares outstanding $x$ shares price

Total Asset Value of Firm = Total asset

Menurut Ang (1997), return (kembalian) adalah tingkat keuntungan yang dinikmati oleh pemodal atas suatu investasi yang dilakukannya. Return saham yang diperoleh dapat berupa keuntungan (capital gain) atau kerugian (capital loss) yang diperoleh dari hasil investasi atau trading saham dalam kurun waktu tertentu. Menurut Jogiyanto (2008), terdapat dua return yakni return realisasi (realized return) dan return ekspektasi (expected return). Perhitungan Return Saham dapat menggunakan rumus sebagai berikut :

$$
\frac{P t-P t-1}{P t-1}
$$

Dimana:

Pt = Harga investasi sekarang

Pt-1 = Harga investasi periode

lalu

\section{Variabel Laten Eksogen (X)}

Variabel laten eksogen merupakan tipe variabel yang tidak dipengaruhi oleh variabel lain dan disimbolkan dengan $\xi$ (dibaca KSI) (Ghozali \& Latan, 2014). Variabel laten endogen yang digunakan dalam penelitian ini adalah Current Ratio, Debt to Equity Ratio, dan Return On Asset.

Current ratio merupakan rasio yang digunakan untuk mengukur bagaimana perusahaan menggunakan aset lancar yang dimiliki dalam melunasi kewajiban lancar. Sederhananya, perusahaan yang mampu mengelola keuangan dengan baik akan mampu melunasi hutang yang dimiliki. Dengan kata lain, dapat dikatakan bahwa perusahaan tersebut likuid. Perusahaan yang tidak likuid disebut insovable. Perhitungan Current Ratio dapat menggunakan rumus sebagai berikut :

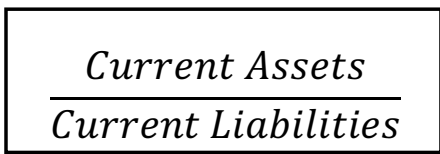

Debt to Equtiy Ratio menggambarkan sampai sejauhmana modal pemilik dapat menutupi utangutang kepada pihak luar (Harahap, 
2008). Rasio ini untuk melihat apakah suatu perusahaan mampu melunasi seluruh kewajiban yang dimiliki dengan menggunakan ekuitas yang ada. Rasio ini juga memberikan petunjuk umum tentang kelayakan dan risiko keuangan perusahaan (Kasmir, 2015). Perhitungan Debt to Equity Ratio dapat menggunakan rumus sebagai berikut :

$\frac{\text { Total Debt }}{\text { Total Equity }}$

Return On Asset (ROA) menunjukkan kemampuan perusahaan dengan menggunakan seluruh aktiva yang dimiliki untuk menghasilkan laba setelah pajak. Rasio ini berguna dalam mengevaluasi efektivitas dan efisiensi manajemen perusahaan dalam mengelola seluruh aktiva perusahaan. Semakin besar ROA, berarti semakin efisien penggunaan aktiva perusahaan atau dengan kata lain dengan jumlah aktiva yang sama bisa dihasilkan laba yang lebih besar, dan sebaliknya (Sudana, 2011). Perhitungan Return On Asset dapat menggunakan rumus sebagai berikut :

$$
\frac{E A T}{\text { Total Assets }}
$$

\section{Jenis dan Sumber Data}

Data yang digunakan adalah jenis data sekunder, yaitu sumber data penelitian yang diperoleh secara tidak langsung melalui media perantara. Data sekunder yang digunakan dalam penelitian ini adalah laporan keuangan perusahaan manufaktur sub sektor Pulp dan Kertas periode 2012-2017 yang diperoleh dari situs Bursa Efek Indonesia, yaitu www.idx.co.id.

\section{Teknik Analisis Data}

Teknik analisis data yang digunakan dalam penelitian ini adalah Partial Least Squares (PLS) dengan menggunakan program WarpPLS 4.0 dan dengan bantuan Microsoft Excel. Teknik ini dipilih karena jumlah variabel laten endogen yang lebih dari satu dan jumlah sampel penelitian yang sedikit.

\section{Statistik Deskriptif}

Statistik deskriptif adalah sebuah metode yang memberikan informasi berguna dengan melakukan pengumpulan dan penyajian sebuah data. Analisis yang dilakukan adalah untuk menilai karakteristik dari sebuah data dimana karakteristik tersebut dapat berupa mean, minimum, dan maksimum yang penyajiannya dapat melalui tabel, grafik, ataupun diagram.

\section{Analisis Jalur (Path Analysis)}

Menurut Widarjono (2015), model analisis jalur yang benar tergantung dari landasan teori yang melatarbelakangi hubungan antarvariabel yang ada. Analisis jalur tidak menyediakan cara melakukan spesifikasi model untuk membentuk teori baru, tetapi hanya sekadar mengestimasi dampak antarvariabel setelah model ditentukan berdasarkan teori yang ada. Model analisis jalur secara persamaan regresi terdiri dari dua persamaan sebagai berikut:

$$
\begin{gathered}
\eta_{1}=\beta_{1} \xi_{1}+\beta_{2} \xi_{2}+\beta_{3} \xi_{3}+\varepsilon_{1} \\
\eta_{2}=\beta_{1} \xi_{1}+\beta_{2} \xi_{2}+\beta_{3} \xi_{3}+\beta_{4} \xi_{4}+
\end{gathered}
$$

$\varepsilon_{2}$

Keterangan:

$$
\begin{aligned}
\eta_{2}= & \begin{array}{l}
\text { Vektor konstruk endogen } \\
(\text { Return Saham) }
\end{array} \\
\eta_{1} \xi_{4}= & \begin{array}{l}
\text { Vektor konstruk endogen dan } \\
\text { eksogen (Nilai Perusahaan) }
\end{array} \\
\xi_{1}= & \begin{array}{l}
\text { Vektor konstruk eksogen } \\
(\text { Current Ratio) }
\end{array}
\end{aligned}
$$




$$
\begin{aligned}
\xi_{2}= & \begin{array}{l}
\text { Vektor konstruk eksogen } \\
(\text { Debt to Equity Ratio })
\end{array} \\
\xi_{3}= & \begin{array}{l}
\text { Vektor konstruk eksogen } \\
(\text { Return on Asset })
\end{array} \\
\beta= & \text { Koefisien } \\
\varepsilon= & \text { error term }
\end{aligned}
$$

Nilai koefisien menentukan arah pengaruh variabel independen terhadap variabel dependen, dimana koefisien bernilai positif $(+)$ mengartikan arah pengaruh yang linear dan koefisien bernilai negatif (-) mengartikan arah pengaruh yang bertolak belakang.

\section{Uji Multikolinearitas}

Average block variance inflation factor (AVIF) dan Average full collinearity VIF (AFVIF) merupakan dua ukuran fit model yang digunakan untuk menguji masalah collinearity di dalam model PLS. Nilai AVIF dan AFVIF akan meningkat jika satu variabel laten untuk model ditambahkan didalamnya juga akan menambahkan full collinearity atau sering disebut multikolinearitas (vertical dan lateral). Nilai yang direkomendasikan untuk kedua ukuran tersebut harus $\leq 3.3$ (Ghozali \& Latan, 2014).

\section{Variance R-Squares dan Q-Squares}

$$
\text { Nilai R-Squares dapat }
$$

digunakan untuk menjelaskan pengaruh variabel laten eksogen tertentu terhadap variabel laten endogen apakah mempunyai pengaruh yang substantive. Nilai R-Squares atau Adjusted $\mathrm{R}^{2} 0.70$, 0.45 , dan 0.25 dapat disimpulkan bahwa model kuat, moderate dan lemah. Batas maksimal untuk nilai ini adalah 0.70 dalam konteks PLS. Jika nilainya lebih besar dari batas tersebut maka kemungkinan model mengalami problem collinearity (Ghozali \& Latan, 2014).

$\mathrm{Q}^{2}$ predictive relevance untuk mengetahui apakah model mempunyai predictive relevance ataukah tidak. $\mathrm{Q}^{2}$ merepresentasi pengukuran bagaimana nilai observed dibangun dari model dan estimasi parameter Nilai $\mathrm{Q}^{2}>0$ menunjukkan bahwa model mempunyai predictive relevance, sedangkan nilai $\mathrm{Q}^{2}$ $<0$ menunjukkan bahwa model kurang memiliki predictive relevance (Ghozali \& Latan, 2014).

\section{Pengujian Hipotesis}

Pengujian hipotesis dilihat dari path coefficients dan $p$-values. Path coefficients merupakan koefisien pada setiap variabel laten eksogen dan endogen yang digambarkan dalam analisis jalur. Sedangkan P-values merupakan pengaruh antar variabel berdasarkan hipotesis yang dibangun melalui prosedur resampling. Nilai signifikansi yang digunakan yaitu twotailed, dengan P-value 0.10 (significance level $=10 \%), 0.05$ (significance level $=5 \%$ ), dan 0.01 (significance level $=1 \%)($ Ghozali \& Latan, 2014).

\section{HASIL DAN PEMBAHASAN Analisis Deskriptif Current Ratio (CR)}

Dalam penelitian ini, nilai $\mathrm{CR}$ tertinggi adalah PT Suparma Tbk pada tahun 2014 sebesar 3,652. Sedangkan nilai $\mathrm{CR}$ terendah adalah PT Alkindo Naratama Tbk pada tahun 2014 sebesar 0,001 . Mean keseluruhan variabel CR dalam 6 periode adalah 1,357.

\section{Debt to Equity Ratio (DER)}

Dalam penelitian ini, nilai DER yang paling tinggi adalah sebesar 2,997 yang dimiliki oleh PT Basuki Rachmat Indonesia Tbk pada tahun 2017. Sedangkan yang paling rendah adalah 0,036 yang dimiliki oleh PT Suparma Tbk pada tahun 2012. Mean keseluruhan dari 8 perusahaan selama 6 periode sebesar 1,464. 


\section{Return On Asset (ROA)}

Dalam penelitian ini, nilai ROA tertinggi adalah PT Toba Pulp Lestari Tbk sebesar 0,110 pada tahun 2016. Sedangkan, PT Kertas Basuki Rachmat Indonesia Tbk juga memiliki nilai ROA yang terendah, yaitu sebesar $-0,107$ pada tahun 2015 dan 2017. Mean ROA dari keseluruhan adalah sebesar 0,019.

\section{Nilai Perusahaan (Tobin's Q)}

Dalam penelitian ini, nilai perusahaan tertinggi pada periode 20122017 adalah PT Alkindo Naratama Tbk pada tahun 2017 sebesar 1,204 dan perusahaan dengan nilai perusahaan (Tobin's Q) terendah adalah PT Suparma Tbk pada tahun 2012 sebesar 0,001. Mean keseluruhan nilai perusahaan (Tobin's Q) adalah sebesar 0,297 .

\section{Return Saham}

Dalam penelitian ini, nilai return tertinggi adalah PT Indah Kiat Pulp \& Paper Tbk sebesar 4,654 pada tahun 2017. Sedangkan nilai return terendah adalah PT Toba Pulp Lestari Tbk yang mencapai kerugian hingga sebesar 0,722 pada tahun 2015. Mean dari keseluruhan return saham sebesar 0,237.

\section{Analisis Jalur (Path Analysis)}

\begin{tabular}{|c|c|c|c|c|c|}
\hline \multirow{3}{*}{ No } & \multirow{3}{*}{$\begin{array}{l}\text { Vari } \\
\text { abel }\end{array}$} & $\begin{array}{l}\text { Hasil } \\
\text { Analysi }\end{array}$ & ji Analisis & \multirow[t]{2}{*}{ Jalur } & \multirow[t]{2}{*}{ (Path } \\
\hline & & $\begin{array}{c}\text { Nilai } \\
\text { Perusa } \\
\text { haan }\end{array}$ & $\begin{array}{l}\text { Return } \\
\text { Saham }\end{array}$ & & \\
\hline & & $\begin{array}{c}\text { Koefisi } \\
\text { en }\end{array}$ & $\begin{array}{c}\text { Keteran } \\
\text { gan }\end{array}$ & $\begin{array}{l}\text { Koef } \\
\text { isien }\end{array}$ & $\begin{array}{c}\text { Keterang } \\
\text { an }\end{array}$ \\
\hline 1 & $\mathrm{CR}$ & 0.286 & Negatif & $\begin{array}{c}0.01 \\
6\end{array}$ & Positif \\
\hline 2 & DER & 0.375 & Negatif & $\begin{array}{c}0.00 \\
6 \\
\end{array}$ & Negatif \\
\hline 3 & $\begin{array}{c}\mathrm{RO} \\
\mathrm{A} \\
\end{array}$ & 0.176 & Positif & $\begin{array}{c}0.33 \\
2 \\
\end{array}$ & Positif \\
\hline 4 & $\begin{array}{c}\text { TOB } \\
\text { IN'S } \\
Q\end{array}$ & - & - & $\begin{array}{c}0.15 \\
0\end{array}$ & Negatif \\
\hline
\end{tabular}

Sumber: data yang telah diolah dengan WarpPLS 4.0

Berdasarkan hasil uji pada tabel, maka diketahui model regresi sebagai berikut:

TOBIN'SQ $=-0.286 \mathrm{CR}-0.375 \mathrm{DER}+$ $0.176 \mathrm{ROA}+\varepsilon 1$

RETSAH $=0.016 \mathrm{CR}-0.006 \mathrm{DER}$ $+0.332 \mathrm{ROA}$

$$
0.150 \mathrm{TOBIN} \text { 'SQ }+\varepsilon 2
$$

Berdasarkan hasil model regresi diatas, menunjukkan hasil interpretasi sebagai berikut : (1) Koefisien regresi variabel current ratio adalah -0.286. Artinya, apabila current ratio mengalami kenaikan satu satuan, maka akan mempengaruhi nilai perusahaan dengan penurunan satu satuan, yaitu sebesar 0.286 dan begitu juga dengan sebaliknya. (2) Koefisien regresi variabel debt to equity ratio adalah -0.375 . Artinya, apabila debt to equity ratio mengalami kenaikan satu satuan, maka akan mempengaruhi nilai perusahaan dengan penurunan satu satuan, yaitu sebesar 0.375 dan begitu juga dengan sebaliknya. (3) Koefisien regresi variabel return on asset adalah 0.176 . Artinya, apabila return on asset mengalami kenaikan satu satuan, maka akan mempengaruhi nilai perusahaan dengan kenaikan satu satuan juga, yaitu sebesar 0.176 dan begitu juga dengan sebaliknya. (4) Koefisien regresi variabel current ratio adalah 0.016 .

Artinya, apabila current ratio mengalami kenaikan satu satuan, maka akan mempengaruhi return saham dengan kenaikan satu satuan yang sama, yaitu sebesar 0.016 dan begitu juga dengan sebaliknya. (5) Koefisien regresi variabel debt to equity ratio adalah 0.006. Artinya, apabila debt to equity ratio mengalami kenaikan satu satuan, maka akan mempengaruhi return saham dengan penurunan satu satuan yang 
sama, yaitu sebesar 0.006 dan begitu juga dengan sebaliknya. (6) Koefisien regresi variabel return on asset adalah 0.332. Artinya, apabila return on asset mengalami kenaikan satu satuan, maka akan mempengaruhi return saham dengan kenaikan satu satuan sebesar 0.332 dan begitu juga dengan sebaliknya. (7) Koefisien regresi variabel nilai perusahaan adalah -0.150 . Artinya, apabila nilai perusahaan mengalami kenaikan satu satuan, maka akan mempengaruhi return saham dengan penurunan satu satuan, yaitu 0.150 dan begitu juga dengan sebaliknya.

\section{Uji Multikolinearitas}

Tabel 2. Hasil Uji Multikolinearitas

\begin{tabular}{|c|c|c|c|}
\hline \multirow{2}{*}{ Konstruk/Laten } & \multicolumn{2}{|c|}{ AVIF } & \multirow{2}{*}{ AFVIF } \\
\hline & TOBIN'SQ & RETSAH & \\
\hline CR & 1.069 & 1.175 & 1.176 \\
\hline DER & 1.207 & 1.391 & 1.391 \\
\hline ROA & 1.155 & 1.195 & 1.319 \\
\hline TOBIN'SQ & - & 1.306 & 1.331 \\
\hline RETSAH & - & - & 1.123 \\
\hline $\begin{array}{l}\text { Sumber: } d a \\
\text { WarpPLS } 4.0\end{array}$ & yang $t$ & diolah & lengan \\
\hline
\end{tabular}

Berdasarkan hasil pengujian yang disajikan pada tabel diatas, dapat diketahui bahwa pada variabel-variabel tidak terdapat masalah multikolinearitas baik vertical maupun lateral dimana seluruh nilai AVIF maupun AFVIF $\leq$ 3.3. Maka, dapat disimpulkan bahwa tidak ada korelasi antar variabel laten eksogen.

\section{Variance R-Squares dan Q-Squares}

Tabel 3. Hasil Uji pada Variabel Laten Endogen

\begin{tabular}{cccc}
\hline $\begin{array}{c}\text { Variabel } \\
\text { Laten } \\
\text { Endogen }\end{array}$ & Nilai $\mathbf{R}^{\mathbf{2}}$ & Kategori & Nilai $^{\mathbf{2}}$ \\
\hline $\begin{array}{c}\text { Nilai } \\
\text { Perusahaan } \\
\text { (TOBIN'SQ) }\end{array}$ & 0.234 & Lemah & 0.232 \\
\hline $\begin{array}{c}\text { Return } \\
\text { Saham } \\
\text { (RETSAH) }\end{array}$ & 0.109 & Lemah & 0.110 \\
\hline $\begin{array}{l}\text { Sumber: data } \\
\text { WarpPLS 4.0 }\end{array}$ & yang & telah diolah & dengan \\
\hline
\end{tabular}

Nilai $\mathrm{R}^{2}$ yang dihasilkan variabel laten endogen TOBINS'Q sebesar 0,234. Hasil penelitian menunjukkan variasi TOBINS'Q yang dapat dijelaskan atau dipengaruhi oleh tiga variabel laten eksogen $\mathrm{CR}$, DER, dan ROA sebesar 23,4\%. Sisanya sebesar $76,6 \%$ dipengaruhi oleh faktor lainnya. Dapat disimpulkan bahwa model ini lemah karena nilai $\mathrm{R}^{2}<0.25$. Nilai $Q$-squared yang dihasilkan model $0.232>0$ yang berarti model mempunyai predictive validity. Nilai $\mathrm{R}^{2}$ yang dihasilkan variabel laten endogen RETSAH sebesar 0,109 yang berarti menunjukkan variasi RETSAH yang dapat dijelaskan atau dipengaruhi oleh empat variabel CR, DER, ROA dan TOBIN'SQ hanya sebesar 10,9\%. Sisanya sebesar $89,1 \%$ dipengaruhi oleh faktor lainnya. Dapat disimpulkan bahwa model ini lemah karena nilai $\mathrm{R}^{2}$ $<0.25$. Nilai $Q$-squared yang dihasilkan model $0.110>0$ yang berarti model mempunyai predictive validity.

\section{Pengujian Hipotesis}

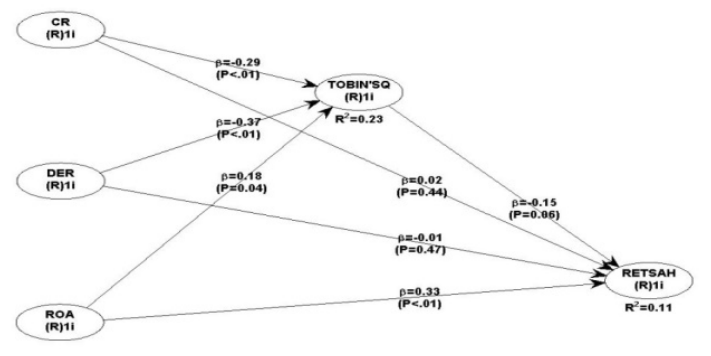

Gambar 3. Hasil Pengujian dalam Kerangka Pemikiran 
Berikut hasil pengujian statistik yang disajikan dalam tabel, antara lain sebagai berikut :

Tabel 4. Hasil Statistik Pengujian Hipotesis

\begin{tabular}{ccccc}
\hline $\begin{array}{c}\text { Hipotes } \\
\text { is }\end{array}$ & Hubungan & $\begin{array}{c}\text { Path } \\
\text { Coefficie } \\
\text { nts }\end{array}$ & P-values & Kesimpulan \\
\hline $\mathrm{H}_{1}$ & $\mathrm{CR} \rightarrow$ TOBIN'SQ & $\begin{array}{c}- \\
0.286^{* * *}\end{array}$ & 0.002 & Signifikan \\
\hline $\mathrm{H}_{2}$ & $\mathrm{DER} \rightarrow$ TOBIN'SQ & $\begin{array}{c}- \\
0.375^{* * *}\end{array}$ & $<0.001$ & Signifikan \\
\hline $\mathrm{H}_{3}$ & $\mathrm{ROA} \rightarrow$ TOBIN'SQ & $0.176^{* *}$ & 0.037 & Signifikan \\
\hline $\mathrm{H}_{4}$ & $\mathrm{CR} \rightarrow$ RETSAH & 0.016 & 0.436 & Tidak signifikan \\
\hline $\mathrm{H}_{5}$ & $\mathrm{DER} \rightarrow \mathrm{RETSAH}$ & -0.006 & 0.475 & Tidak Signifikan \\
\hline $\mathrm{H}_{6}$ & $\mathrm{ROA} \rightarrow \mathrm{RETSAH}$ & $0.332^{* * *}$ & $<0.001$ & Signifikan \\
\hline $\mathrm{H}_{7}$ & $\begin{array}{c}\mathrm{TOBIN} \text { 'SQ } \rightarrow \\
\mathrm{RETSAH}\end{array}$ & $-0.150^{*}$ & 0.063 & Tidak signifikan \\
\hline
\end{tabular}

Sumber: data yang telah diolah dengan WarpPLS 4.0 Note: *** $p<0.01$, ** $p<0.05$, * $p<0.1$ tingkat signifikan statistik

Hasil penelitian dari pengujian hipotesis dapat disimpulkan bahwa $\mathrm{H}_{1}$ menunjukkan pengaruh $\mathrm{CR}$ terhadap Nilai Perusahaan memiliki nilai koefisien -0.286 dan $\mathrm{P}$ value $0.002<0.1$ sehingga dapat dinyatakan bahwa CR berpengaruh negatif signifikan terhadap nilai perusahaan. Sedangkan, $\mathrm{H}_{2}$ menunjukkan pengaruh DER terhadap Nilai Perusahaan memiliki nilai koefisien -0.375 dan $\mathrm{P}$ value $<0.001$ sehingga dapat dinyatakan bahwa DER berpengaruh negatif signifikan terhadap nilai perusahaan.

Sementara itu, $\mathrm{H}_{3}$ menunjukkan pengaruh ROA terhadap Nilai Perusahaan memiliki nilai koefisien sebesar 0.176 dan $\mathrm{P}$ value $0.037<0.1$ sehingga dapat dinyatakan bahwa ROA berpengaruh positif signifikan terhadap nilai perusahaan. $\mathrm{H}_{4}$ menunjukkan pengaruh CR terhadap Return Saham memiliki nilai koefisien 0.016 dan $\mathrm{P}$ value $0.436>0.1$ sehingga dapat disimpulkan bahwa CR berpengaruh positif tidak signifikan terhadap return saham. $\mathrm{H}_{5}$ menunjukkan pengaruh DER terhadap Return Saham memiliki nilai koefisien -0.006 dan $\mathrm{P}$ value $0.475>0.1$ sehingga dapat disimpulkan bahwa DER berpengaruh negatif tidak signifikan terhadap return saham. $\mathrm{H}_{6}$ menunjukkan pengaruh ROA terhadap Return Saham memiliki nilai koefisien 0.332 dan $\mathrm{P}$ value $<0.001$ sehingga dapat disimpulkan bahwa ROA berpengaruh positif signifikan terhadap return saham. Sementara itu, $\mathrm{H}_{7}$ pengaruh Nilai Perusahaan terhadap Return Saham memiliki nilai koefisien 0.150 dan $\mathrm{P}$ value 0.063 yang berarti $\mathrm{P}$ value $<0.1$ sehingga dapat disimpulkan bahwa nilai perusahaan berpengaruh negatif signifikan terhadap return saham.

\section{Pengaruh Current Ratio terhadap Nilai Perusahaan (Tobin's Q)}

Berdasarkan hasil pengujian pengaruh Current Ratio terhadap Nilai Perusahaan, $\mathrm{H}_{1}$ menunjukkan bahwa Current Ratio berpengaruh negatif signifikan terhadap Nilai Perusahaan. Hal tersebut mengartikan bahwa semakin meningkatnya Current Ratio akan mempengaruhi nilai perusahaan yang semakin menurun dan juga sebaliknya semakin menurun current ratio maka semakin meningkat nilai perusahaan. Penyebab tidak sejalannya arah pengaruh Current Ratio terhadap Nilai Perusahaan dikarenakan oleh nilai perusahaan yang baik apabila nilai pasar lebih tinggi dibandingkan nilai buku aset perusahaan.

Oleh sebab itu, current ratio yang tinggi menandakan bahwa perusahaan memiliki aset lancar yang tinggi sehingga secara langsung akan mempengaruhi nilai buku aset, maka dari itu semakin tingginya current ratio akan menyebabkan semakin menurunnya nilai perusahaan. Hasil penelitian ini sejalan dengan hasil penelitian Jacob \& Taslim (2017). Namun, bertentangan dengan penelitian 
Putri, et.al, (2016), Adelina, et.al, (2014); Chotimah \& Amanah (2013) yang menyatakan bahwa Current Ratio (CR) tidak berpengaruh signifikan terhadap nilai perusahaan.

\section{Pengaruh Debt to Equity Ratio terhadap Nilai Perusahaan (Tobin's Q)}

Berdasarkan hasil pengujian pengaruh Debt to Equity Ratio terhadap Nilai Perusahaan, $\mathrm{H}_{2}$ menunjukkan bahwa Debt to Equity Ratio berpengaruh negatif signifikan terhadap Nilai Perusahaan. Hal tersebut menandakan bahwa semakin meningkatnya debt to equity ratio akan mempengaruhi nilai perusahaan yang semakin mengalami penurunan dan semakin menurun debt to equity ratio maka semakin meningkat nilai perusahaan. Hal ini sejalan dengan yang seharusnya, dimana debt to equity ratio yang tinggi berarti hutang yang dimiliki perusahaan tinggi sehingga nilai perusahaan di mata pasar akan dipandang kurang baik karena para investor menilai perusahaan tersebut tidak mampu mengatasi kewajiban yang seharusnya dipenuhi.

Tentunya para calon investor tidak akan menanamkan sahamnya pada perusahaan yang mempunyai hutang yang tinggi. Hutang yang tinggi mengindikasikan risiko investasi yang tinggi. Hasil penelitian ini tidak sejalan dengan penelitian terdahulu, dan tidak didukung oleh penelitian Chotimah \& Amanah (2013) bahwa Debt to Equity Ratio (DER) berpengaruh positif signifikan terhadap nilai perusahaan, dimana pernyataan tersebut bertolak belakang dengan hasil penelitian Mahendra, Artini dan Suarjaya (2012) dan Sianturi (2015) yang menyatakan bahwa Debt to Equity Ratio (DER) berpengaruh negatif tidak signifikan terhadap nilai perusahaan. Kedua pernyataan tersebut tidak didukung oleh penelitian Adelina, et.al, (2014) yang menyatakan bahwa Debt to Equity Ratio (DER) tidak berpengaruh signifikan terhadap nilai perusahaan. Perbedaan hasil penelitian tersebut dapat disebabkan oleh perbedaan objek penelitian, periode objek penelitian, dan faktor eksternal yang mempengaruhi objek penelitian.

\section{Pengaruh Return On Asset terhadap Nilai Perusahaan (Tobin's Q)}

Berdasarkan hasil pengujian pengaruh Return On Asset terhadap Nilai Perusahaan, $\mathrm{H}_{3}$ menunjukkan bahwa Return On Asset berpengaruh positif signifikan terhadap Nilai Perusahaan. Hal tersebut dapat diartikan bahwa apabila ROA mengalami peningkatan maka akan mempengaruhi nilai perusahaan yang juga meningkat. Sebaliknya, apabila ROA mengalami penurunan maka nilai perusahaan turut mengalami penurunan. Hasil penelitian ini sejalan dengan pendapat para ahli yang telah dikemukakan, dimana return on asset yang meningkat menunjukkan bahwa apabila laba yang diperoleh dari total asset yang dimiliki jika semakin tinggi akan secara langsung mempengaruhi nilai perusahaan yang turut mengalami peningkatan.

Dengan pasar mengetahui bahwa suatu perusahaan memiliki dan mampu menghasilkan laba yang cukup tinggi serta pergerakkan tingkat laba yang dihasilkan mengalami peningkatan, hal tersebut tentu saja akan menjadi pandangan positif bagi para investor maupun pelaku pasar modal lainnya. Hasil penelitian ini sejalan dengan hasil penelitian dari peneliti terdahulu yang dilakukan oleh Putri, et.al, (2016). Namun, pernyataan tersebut berbeda dengan hasil penelitian Chotimah \& Amanah (2013) yang menyatakan bahwa Return On Asset (ROA) 
berpengaruh negatif signifikan terhadap nilai perusahaan dan juga bertentangan dengan penelitian Tjandrakirana \& Monika (2014) yang menyatakan bahwa Return On Assets (ROA) tidak berpengaruh signifikan terhadap nilai perusahaan.

\section{Pengaruh Current Ratio terhadap Return Saham}

Berdasarkan hasil pengujian pengaruh Current Ratio terhadap Return Saham, $\mathrm{H}_{4}$ menunjukkan bahwa Current Ratio berpengaruh negatif tidak signifikan terhadap Return Saham. Hal tersebut dapat diartikan bahwa apabila current ratio pada perusahaan manufaktur sub sektor pulp dan kertas semakin meningkat maka akan mempengaruhi return saham dengan semakin meningkat dan begitu juga semakin menurun current ratio maka return saham semakin menurun.

Hal tersebut sejalan dengan yang seharusnya, dimana current ratio yang tinggi akan mempengaruhi tingginya return saham. Current ratio yang baik menandakan bahwa perusahaan tersebut likuid. Apabila current ratio tinggi, maka pasar akan menilai positif kinerja perusahaan tersebut dimana nantinya akan mempengaruhi harga saham yang juga tinggi dan berdampak pada tingginya return saham sehingga dapat memberikan kemakmuran kepada para pemegang saham. Hasil penelitian tersebut tidak sejalan dengan penelitian terdahulu yang dilakukan oleh Dewi (2016) yang menyatakan bahwa Current Ratio (CR) berpengaruh positif signifikan terhadap return saham, serta penelitian dari Erari (2014); Febrioni (2016); Chotimah dan Amanah (2013) yang menyatakan bahwa Current Ratio (CR) tidak berpengaruh signifikan terhadap return saham. Perbedaan hasil penelitian tersebut dapat disebabkan oleh perbedaan objek penelitian, periode objek penelitian, dan faktor eksternal yang mempengaruhi objek penelitian.

\section{Pengaruh Debt to Equity Ratio terhadap Return Saham}

Berdasarkan hasil pengujian pengaruh Debt to Equity Ratio terhadap Return Saham, $\mathrm{H}_{5}$ menunjukkan bahwa Debt to Equity Ratio berpengaruh negatif tidak signifikan terhadap Return Saham. Hal tersebut mengartikan bahwa DER yang semakin meningkat tidak mempengaruhi ikut meningkatnya return saham, dan begitu juga sebaliknya. DER yang tinggi mengartikan bahwa hutang yang dimiliki perusahaan tinggi yang akan berdampak pada kinerja keuangan yang buruk dan ketergantungan perusahaan terhadap pihak luar yang semakin tinggi. Tingginya hutang akan menyebabkan dibebankannya hutang kepada pemegang saham sehingga bagi pemegang saham akan meningkatkan risiko investasi.

Hasil penelitian ini sejalan dengan hasil penelitian Erari (2014), tetapi bertentangan dengan hasil penelitian Siburian \& Daulay (2013); Susilowati \& Turyanto (2011); Dewi (2016); Chotimah \& Amanah (2013) menunjukkan bahwa Debt to Equity Ratio (DER) berpengaruh positif signifikan terhadap return saham. Namun, pernyataan tersebut juga ditentang oleh hasil penelitian Gunadi \& Kesuma (2015) yang menyatakan bahwa Debt to Equity Ratio (DER) berpengaruh negatif signifikan terhadap return saham.

\section{Pengaruh Return On Asset Ratio terhadap Return Saham}

Berdasarkan hasil pengujian pengaruh Return On Asset terhadap Return Saham, $\mathrm{H}_{6}$ menunjukkan bahwa Return On Asset berpengaruh positif 
signifikan. Hal tersebut mengartikan bahwa apabila return on asset meningkat maka return saham akan mengalami peningkatan juga. Begitu juga sebaliknya, semakin menurut return on asset maka return saham semakin menurun juga. Hal ini sejalan dengan yang seharusnya karena apabila perusahaan mampu memperoleh laba yang tinggi atas investasi yang dilakukan maka menggambarkan bahwa kinerja keuangan perusahaan dalam memperoleh laba dalam kategori baik. Kinerja keuangan yang baik akan mempengaruhi harga saham menjadi naik dan tinggi di pasar sehingga akan berpengaruh terhadap return yang juga meningkat.

Hasil penelitian ini sejalan dengan hasil penelitian terdahulu yang dilakukan oleh Gunadi \& Kesuma (2014); Dewi (2016); Erari (2014),; Chotimah \& Amanah (2013). Bertentangan dengan hasil penelitian ini, hasil penelitian Siburian \& Daulay (2013), Syahputri \& Herlambang (2015) yang menyatakan bahwa Return On Asset (ROA) berpengaruh positif tidak signifikan terhadap return saham. Tetapi, hasil penelitian Mahmudah \& Suwitho (2016) menyatakan bahwa Return On Assets (ROA) berpengaruh negatif tidak signifikan terhadap return saham. Ketiga hasil penelitian tersebut tidak didukung oleh penelitian Susilowati \& Turyanto (2011); Febrioni (2016); Oktyawati \& Agustia (2014) yang menyatakan bahwa Return On Assets (ROA) tidak berpengaruh signifikan terhadap return saham.

\section{Pengaruh Nilai Perusahaan (Tobin's Q) terhadap Return Saham}

Berdasarkan hasil pengujian pengaruh Nilai Perusahaan terhadap Return Saham, $\mathrm{H}_{7}$ menunjukkan bahwa Nilai Perusahaan berpengaruh negatif signifikan terhadap Return Saham. Hal tersebut mengartikan bahwa apabila nilai perusahaan meningkat maka return saham akan mengalami penurunan dan sebaliknya, apabila nilai perusahaan menurun maka return saham meningkat. Hal ini tidak sejalan dengan yang seharusnya, dimana nilai perusahaan yang baik dapat terjadi apabila memiliki kinerja keuangan yang baik dikarenakan penilaian suatu perusahaan digambarkan dari kinerja keuangan yang dicerminkan oleh harga saham yang dimiliki sehingga nilai perusahaan yang meningkat maka return saham juga akan mengalami peningkatan. Namun, pengaruh nilai perusahaan terhadap return saham yang berbanding terbalik tersebut dapat disebabkan oleh faktor-faktor diluar internal perusahaan, seperti nilai kurs, tingkat inflasi, maupun suku bunga. Hasil penelitian ini tidak sejalan dengan hasil penelitian dari peneliti terdahulu dan bertentangan dengan hasil penelitian yang dilakukan Rahman \& Khairunnisa (2016), dan Kurniadi, et.al, (2013) yang menyatakan bahwa nilai perusahaan berpengaruh positif signifikan terhadap return saham. Perbedaan hasil penelitian tersebut dapat disebabkan oleh perbedaan objek penelitian, periode objek penelitian, dan faktor eksternal yang mempengaruhi objek penelitian.

\section{PENUTUP}

Berdasarkan pengujian yang telah dilakukan pada perusahaan manufaktur sub sektor pulp dan kertas yang terdaftar di Bursa Efek Indonesia periode 2012-2017, maka hasil penelitian dapat disimpulkan sebagai berikut : (1) Current Ratio dan Debt to Equity Ratio berpengaruh negatif signifikan terhadap Nilai Perusahaan. Sedangkan, Return On Asset berpengaruh positif signifikan terhadap Nilai Perusahaan. (2) Current Ratio berpengaruh positif tidak signifikan 
terhadap Return Saham, Return On Asset berpengaruh positif signifikan terhadap Return Saham, serta Debt to Equity Ratio dan Nilai Perusahaan berpengaruh negatif signifikan terhadap Return Saham. (3) Current Ratio, Debt to Equity Ratio dan Return On Asset dapat menjelaskan Nilai Perusahaan sebesar 23,4\%. Sedangkan, Current Ratio, Debt to Equity Ratio, Return On Asset, dan Nilai Perusahaan dapat menjelaskan Return Saham sebesar $10,9 \%$.

Berdasarkan hasil penelitian yang dihasilkan, maka saran-saran yang dapat diberikan kepada pihak-pihak tertentu sebagai berikut : (1) Bagi investor, diharapkan melakukan analisis lebih dalam dan lebih luas agar mengetahui perusahaan mana yang memiliki kinerja keuangan yang baik, dapat memberikan return yang tinggi, dan memiliki nilai perusahaan yang baik sebelum melakukan investasi. (2) Bagi perusahaan, diharapkan menganalisa dan mengevaluasi kembali yang menyebabkan kinerja keuangan bekerja kurang baik, serta meningkatkan dalam pengelolaan aset dan mengatasi nilai perusahaan yang undervalue sehingga dapat menarik investor lebih banyak dibandingkan sebelumnya. (3) Bagi akademis, diharapkan menggunakan rasio keuangan yang lainnya atau menggunakan objek penelitian yang berbeda dengan sampel yang lebih banyak agar hasil penelitian lebih akurat sehingga dapat dilakukan perbandingan terhadap peneliti terdahulu.

Berdasarkan penelitian yang telah dilakukan, adapun terdapat beberapa keterbatasan yang menjadi kelemahan dalam penelitian ini, antara lain sebagai berikut : (1) Sampel yang digunakan hanya berjumlah 48 sampel dan objek penelitian hanya berjumlah 8 perusahaan. (2) Variabel laten eksogen yang digunakan hanya mengambil perwakilan dari 3 rasio keuangan dan 1 rasio keuangan tidak gunakan, yaitu rasio aktivitas.

\section{UCAPAN TERIMA KASIH}

Penelitian ini sepenuhnya didukung dan dibiayai oleh Kementrian Pendikan dan Kebudayaan Republik Indonesia, Badan Riset dan Inovasi Nasional, Tahun Anggaran 2020 dengan nomor kontrak: 107/SP2H/PPM/DRPM/2020

\section{DAFTAR PUSTAKA}

Adelina, S., Agusti, R., \& Basri, Y. M. (2014). Pengaruh Rasio Likuiditas, Leverage Dan Profitabilitas Terhadap Nilai Perusahaan Pada Industri Barang Konsumsi Yang Terdaftar Di Bursa Efek Indonesia Tahun 2010-2012. JOM FEKON 1(2):1-15.

Ang, R. (1997). Buku Pintar Pasar Modal Indonesia. Jakarta: Media Staff Indonesia.

Chotimah, C., \& Amanah, L. (2013). Analisis Rasio Keuangan Terhadap Return Saham Dan Nilai Perusahaan. Jurnal Ilmu \& Riset Akuntansi, 2(12):1-23.

Dewi, P., E. (2016). Pengaruh Rasio Likuiditas, Profitabilitas, Solvabilitas, Aktivitas dan Penilaian Pasar terhadap Return Saham. Jurnal Ilmiah Akuntansi, 1(2):109-132.

Erari, A. (2014). Analisis Pengaruh Current Ratio, Debt to Equity Ratio, dan Return On Asset terhadap Return Saham pada Perusahaan Pertambangan di Bursa Efek Indonesia. Jurnal Manajemen \& Bisnis, 5(2):174191. 
Febrioni, R. (2016). Pengaruh Return On Asset, Return On Equity, Earning Per Share, Dan Current Ratio Terhadap Return Saham (Pada Perusahaan Yang Terdaftar di Indeks LQ45 di Bursa Efek Indonesia Tahun 2011-2015). E-Proceeding of Management, 3(3):3439-3449.

Ghozali, I., \& Latan, H. (2014). Partial Least Squares Konsep, Metode dan Aplikasi Menggunakan Program WarpPLS 4.0 Edisi Kedua. Semarang: Badan Penerbit Universitas Diponegoro. Gunadi, G., G., \& Kesuma, I., K. (2015). Pengaruh ROA, DER, EPS Terhadap Return Saham Perusahaan Food and Beverage BEI. E-Jurnal Manajemen Unud, 4(6).

Harahap, S.,S. (2008). Analisis Kritis atas Laporan Keuangan. Jakarta: PT. Raja Grafindo Persada.

Husnan, S. (2009). Dasar-Dasar Teori Portofolio dan Analisis Sekuritas Edisi 3. Yogyakarta: AMPYKPN.

Jacob, J., \& Taslim, F. A. (2017). The Impact of The Ratio of Liquidity, Activity and Profitability Towards Company Value With Dividend Policy As Intervening Variables. IOSR Journal of Business and Management (IOSR-JBM), 19(10): 1-7.

Jogiyanto, H., M. (2008). Teori Portofolio dan Analisis Investasi Edisi Kelima, Cetakan Pertama. Yogyakarta: BPFE.

Kasmir. (2015). Analisis Laporan Keuangan. Jakarta: Rajawali Pers.

Kurniadi, A., Achsani, N., A., \& Sasongko, H. (2013). Kinerja Keuangan Berbasis Penciptaan Nilai, Faktor Makroekonomi dan Pengaruhnya Terhadap Return
Saham Sektor Pertanian. Jurnal Akuntansi dan Keuangan, 15(2): 63-74.

Mahendra, A., Artini, L.,G., \& Suarjaya, A. A. (2012). Pengaruh Kinerja Keuangan terhadap Nilai Perusahaan pada Perusahaan Manufaktur di Bursa Efek Indonesia. Jurnal Manajemen, Strategi Bisnis, dan Kewirausahaan, 6(2).

Mahmudah, U., \& Suwitho. (2016). Pengaruh ROA, Firm Size dan NPM terhadap Return Saham pada Perusahaan Semen. Jurnal Ilmu dan Riset Manajemen, 5(1): 1-15.

Oktyawati, D., \& Agustia, D. (2014). Pengaruh Profitabilitas, Leverage, dan Nilai Perusahaan terhadap Smoothing dan Return Saham pada Perusahaan Manufaktur Yang Terdaftar di Bursa Efek Indonesia (BEI). Jurnal Akuntansi \& Auditing, 10(2):195-214.

Putri, R., H., Zahroh, \& Endang, M., G. (2016). Pengaruh Rasio Likuiditas dan Rasio Profitabilitas terhadap Nilai Perusahaan (Studi pada Perusahaan Sektor Industri Barang Konsumsi yang Terdaftar di BEI Tahun 20122014). Jurnal Administrasi Bisnis, 38(2): 331-338.

Rahman, G., D., \& Khairunnisa. (2016). Pengaruh Tobin's Q, Inflasi, Suku Bunga, dan Nilai Tukar Terhadap Return Saham. EProceeding of Management, 3(1): 331-338.

Sianturi, M., W. (2015). Pengaruh Kinerja Keuangan terhadap Nilai Perusahaan Manufaktur Sektor Industri Barang Konsumsi di BEI. E-Journal 
Administrasi Bisnis, 3(2):282296.

Siburian, F., E., \& Daulay, M. (2013). Analisis Pengaruh Debt to Equity Ratio (DER), Return On Assets (ROA) terhadap Return Saham pada Perusahaan Perbankan Yang Terdaftar di Bursa Efek Indonesia. Jurnal Ekonomi dan Keuangan, 1(6): 25-32.

Sudana, I., M. (2011). Manajemen Keuangan Teori dan Praktik. Jakarta: Erlangga.

Sujarweni, V., W. (2016). Kupas Tuntas Penelitian Akuntansi dengan SPSS. Yogyakarta: Pustaka Baru Press.

Sujarweni, V., W. (2017). Analisis Laporan Keuangan Teori, Aplikasi dan Hasil Penelitian. Yogyakarta: Pustaka Baru Press.

Susanto, E. (2002). Analisis FaktorFaktor yang Mempengaruhi Kebijakan Deviden di BEJ Periode 1999.

Susilowati, Y., \& Turyanto, T. (2011). Reaksi Signal Rasio Profitabilitas dan Rasio Solvabilitas terhadap Return Saham Perusahaan. Dinamika Keuangan dan Perbankan, 3(1): 17-37.

Syahputri, R., \& Herlambang, L. (2015). Pengaruh ROA, NPM, EPS terhadap Return Saham pada Emiten Jakarta Islamic Index Tahun 2010-2013. JESIT 2(4): 340-355.

Tjandrakirana, H. R., \& Monika, M. (2014). Pengaruh Kinerja Keuangan terhadap Nilai Perusahaan pada Manufaktur Yang Terdaftar di Bursa Efek Indonesia. Jurnal Manajemen dan Bisnis Sriwijaya, 12(1).
Widarjono, A. (2015). Analisis Multivariat Terapan Dengan Program SPSS, AMOS, dan SmartPLS Edisi Kedua. Yogyakarta: UPP STIM. 